\title{
Pengembangan Database Untuk Analisa Pembuatan Pakan Pada Agribisnis Peternakan Unggas
}

\author{
Tri Retnasari \\ Program studi Teknik Informatika, STMIK Nusa Mandiri Jakarta \\ 1tri.trs@nusamandiri.ac.id
}

\begin{abstract}
Abstrak - Pakan merupakan komponen terbesar dalam usaha peternakan ternak (sekitar $60-70 \%$ ), sehingga berpengaruh besar terhadap produktifitas. Dalam proses penghitungan formulasi pakan ternak, sangat diperlukan adanya suatu ketelitian dan kewaspadaan, agar kandungan nutrisinya tidak kurang atau melebihi kebutuhan ternak. Oleh karena itu pengembangan dan pemanfaatannya memerlukan keterpaduan antara Sistem Informasi, Program Formulasi dan Manufaktur pakan yang tepat. Teknologi komputer terhadap pengolahan data formulasi pakan ternak akan mempermudah dan meningkatkan kecepatan proses menganalisa kandungan nutrisi pakan secara optimal dan berimbang (nutrisi tidak kurang maupun melebihi kebutuhan ternak) yang dapat diselesaikan dalam hitungan menit dibanding perhitungan secara manual, sehingga dapat diproduksi pakan yang berkualitas dan menghasilkan produktivitas agribisnis yang meningkat. Untuk mengetahui bagaimana informasi hasil perhitungan formulasi pakan ternak unggas disajikan berdasarkan struktur basis data, maka dibutuhkan sistem yang dapat mengolah data tersebut. Sistem yang dikembangkan didisain sesuai dengan karakteristik data yang akan diolah. Tujuan dari database system adalah untuk mengelola data yang digunakan dan dibuat guna mendukung analisa pembuatan pakan oleh staff divisi/bagian pakan dan pemilik perusahaan.
\end{abstract}

Kata Kunci- Teknologi,. Pakan Ternak, Database System.

\section{Pendahuluan}

\section{A. Latar Belakang}

CV. Mitra Kurnia Mandiri adalah perusahaan yang bergerak dibidang agribisnis peternakan unggas. Dalam menjalankan usahanya, CV. Mitra Kurnia Mandiri juga mengalami kesulitan dalam menghadapi masalah produktifitas terutama masalah untuk pakan unggas. Pakan merupakan komponen terbesar dalam usaha peternakan unggas (sekitar 60-70\%), sehingga berpengaruh besar terhadap produktifitas. Oleh karena itu untuk pengembangan dan pemanfaatannya memerlukan keterpaduan antara Sistem Informasi, Program Formulasi dan Manufaktur pakan yang tepat. Dalam proses analisa pembuatan pakan, sangat diperlukan adanya suatu ketelitian dan kewaspadaan, agar kandungan nutrisinya tidak kurang atau melebihi kebutuhan ternak. Oleh karena itu, dalam menanganinya harus dilakukan dengan teliti dan waspada, baik dalam menangani tentang masalah persentase bahan baku yang akan digunakan dengan tepat.

Teknologi komputer terhadap pengolahan data pembuatan pakan ternak unggas akan sangat membantu CV. Mitra Kurnia Mandiri dalam mempermudah dan meningkatkan kecepatan proses menganalisa kandungan nutrisi pakan, sehingga dapat diproduksi pakan yang berkualitas dan menghasilkan produktivitas agribisnis yang meningkat. Pemanfaatan database terintegrasi sangat penting untuk dikembangkan [5]. Hal ini, berdampak pada penyajian data, informasi secara cepat dan akurat [7].

\section{B. Scope}

Ruang lingkup hanya pada kegiatan yang dimulai dari pendataan permintaan pembuatan pakan, pengolahan data bahan baku termasuk masing-masing nutrisi dan harga per kilogram beserta maksimal anjuran penggunaannya, pengolahan data unggas, proses formulasi pakan hingga didapat nutrisi yang optimal dan berimbang beserta total harga formulasi per kilogram, proses analisa hasil formulasi pakan yang telah dibuat, sampai dengan pembuatan laporan data bahan baku, laporan hasil formulasi pakan yang berisi data formulasi beserta penggunaan komposisi bahan baku yang telah digunakan beserta laporan analisa formulasi pakan, tetapi jika ada penyimpangan terhadap nilai nutrisi relatif, maka dibuatkan juga laporan analisa perbaikan formulasi. Hasil dari perhitungan dan analisa yang sudah dibuat tersebut akan diserahkan kepada manajer produksi divisi pakan ternak unggas dan pemilik perusahaan sebagai laporan formulasi..

\section{System Definition}

Dari database planning yang akan dibuat, maka permasalahan yang ada di sistem perusahaan akan dibatasi sebagai berikut :

1. Pencatatan bahan baku sebagai bahan dasar untuk formulasi pakan memerlukan waktu lama dan sering terjadi kesalahan pada setiap kandungan bahan.

2. Sering terjadi kesalahan-kesalahan dalam memformulasikan pakan ternak unggas dan memerlukan waktu lama untuk perhitungan karena terlalu banyaknya data pembuatan formulasi pakan sehingga laporan analisa formulasi pakan kurang optimal.

\section{Mission Statement}

Tujuan dari database system adalah untuk mengelola data yang digunakan dan dibuat guna mendukung analisa pembuatan pakan oleh staff divisi/bagian pakan dan pemilik perusahaan.

\section{TINJAUAN PUSTAKA}

\section{A. Database Integrated System}

Database integrated system merupakan media penyimpanan data secara terpusat [5]. Database integrated system dapat melakukan penyimpanan data secara lengkap kedalam database sehingga berdampak pada penyajian data, 
informasi dengan cepat dan akurat dalam mendapatkan kembali informasi tersebut. Sistem terpadu berfungsi sebagai sarana atau media penyimpanan data dan informasi yang memiliki keserderhanaan, kehandalan dan portabilitas yang tinggi [3].

Sistem database terpadu memiliki keunggulan yaitu:

1. Integritas data lebih maksimal dan redundansi data dapat diminimalkan, sehingga data menjadi akurat dan konsisten dalam meningkatkan keandalan data.

2. Keamanan data lebih terjaga.

3. Pelestarian data akan menjadi lebih baik karena pengelola dilakukan terpusat.

4. Pengguna lebih mudah untuk mendapatkan data dan informasi karena kesederhanaan dalam desain database tunggal.

5. Portabilitas data dan administrasi database secara umum lebih mudah.

6. Efektifivas penggunaan daya listrik, sumber daya manusia dan biaya pemeliharaan sistem database dapat dioptimalkan.

7. Semua informasi dapat diakses pada saat yang sama dari lokasi yang berbeda.

\section{B. Basis Data dan SQL}

Basis data merupakan Media untuk menyimpan data agar dapat diakses dengan mudah dan cepat [6]. Basis data atau database menurut [8] adalah "Sebuah koleksi atau kumpulan data yang saling berhubungan (relation), disusun menurut aturan tertentu secara logis, sehingga menghasilkan informasi". Sedangkan menurut [4] menjelaskan bahwa database adalah "Sebagai kumpulan terorganisasi dari datadata yang berhubungan sedemikian rupa sehingga mudah disimpan, dimanipulasi, serta dipanggil penggunanya".

SQL adalah bahasa yang digunakan untuk mengelola data pada Database [6]. Sedangkan Menurut [1] menjelaskan bahwa "SQL (Structured Query Language) adalah sebuah bahasa yang dipergunakan untuk mengakses data dalam basis data relasional”. SQL juga dapat diartikan sebagai antar muka standar untuk sistem manajemen basis data relasional, termasuk sistem yang beroperasi pada komputer pribadi.

\section{Entity Relationship Diagram (ERD)}

Entity Relationship Diagram (ERD) merupakan notasi grafis dalam pemodelan data konseptual yang mendeskripsikan hubungan antara penyimpanan [2]. ERD digunakan untuk memodelkan struktur data dan hubungan antar data, karena hal ini kompleks. ERD menggunakan sejumlah notasi dan simbol untuk menggambarkan struktur dan hubungan antar data, pada dasarnya ada tiga macam symbol yang digunakan yaitu":

1. Entity

: Adalah suatu objek yang dapat diidentifikasikan dalam lingkungan pemakai, sesuatu yang penting bagi pemakai dalam konteks sistem yang akan dibuat.
Atribut : Entity mempunyai elemen yang disebut atribut, dan berfungsi mendeskripsikan karakter entity.

3. - Hubungan : Relationship, sebagaimana hanya entity maka dalam hubungan pun harus dibedakan antara hubungan atau bentuk hubungan antar entity dengan isi dan hubungan itu sendiri.

Secara umum ada dua langkah dalam membuat ERD. Langkah pertama adalah membuat ERD awal untuk mendapatkan sebuah rancangan database yang minimal dapat mengakomodasi kebutuhan penyimpanan data terhadap sistem yang sedang kita tuju. Selain itu dapat dilakukan optimasi diagram E-R (final design) dengan mempertimbangkan anomalianomali dan aspek-aspek efisiensi, kinerja dan fleksibilitas[2].

Tahap-tahap pembuatan ERD awal yaitu [2]:

1. Mengidentifikasi dan menetapkan seluruh himpunan entitas (entity)yang akan terlihat.

2. Menentukan atribut-atribut key dari masingmasing himpunan entitas.

3. Menentukan primary key dari setiap entitas yang ada.

4. Mengidentifikasi dan menetapkan seluruh himpunan relasi diantara himpunan entitasentitas yang ada beserta foreign key-nya.

5. Menentukan derajat atau kardinalitas relasi untuk setiap himpunan relasi.

\section{REQUIREMENT COLLECTION AND ANALYSIS}

Fact finding yang telah dilakukan adalah melakukan wawancara dengan pemilik CV. Mitra Kurnia Mandiri dan bagian yang terkait dengan sistem pembuatan formulasi pakan pada CV. Mitra Kurnia Mandiri. Dalam perhitungan formulasi pakan untuk unggas, terdapat beberapa tahapan yang ada dalam sistem ini adalah:

1. Staff Administrasi Sapronak \& Obat menyerahkan memo atas perintah pemilik perusahaan sebagai permintaan untuk membuat data formulasi pakan unggas kepada staff divisi/bagian pakan. Untuk melakukan pencatatan dan pemilihan bahan baku yang akan digunakan sebagai bahan pakan ternak unggas, staff divisi/bagian pakan memeriksa daftar bahan baku yang ada di arsip bahan baku.

2. Setelah bahan baku dipilih oleh staff divisi/bagian pakan sebagai bahan utama pakan ternak unggas, setiap bahan baku tersebut harus diperiksa kandungan nutrisinya di laboratorium, maka staff divisi/bagian pakan memberikan contoh bahan baku ke bagian laboratorium untuk dianalisa kandungan nutrisinya. Setelah dianalisa, data tersebut kemudian dicatat kedalam data nutrisi bahan baku, yang kemudian diberikan lagi ke Staff divisi/bagian pakan.

3. Penghitungan formulasi pakan yang dilakukan dengan menentukan bahan baku yang akan digunakan, lalu 
menambahkan komposisi bahan baku secara bertahap hingga akhirnya mencapai $100 \%$. Dalam setiap tahap penghitungan selalu dilakukan pencocokan terhadap standar nutrisi relatif. Jika ada penyimpangan terhadap nilai nutrisi relatif, tahap berikutnya harus menambahkan bahan baku yang sesuai (sumber energi atau sumber protein). Proses ini dilakukan berulang-ulang, hingga didapat komposisi pakan $100 \%$ dan didapat angka nutrisi sesuai dengan kebutuhan.

4. Setelah melakukan tahap perhitungan formulasi, selanjutnya menganalisa hasil perhitungan formulasi. Analisa perhitungan formulasi ditentukan berdasarkan kebutuhan:

a. Untuk hidup pokok $=(\mathrm{BB} \times 0,0016) / 0,61$

BB : bobot badan (gram)

0,0016: kehilangan nitrogen endogen sebesar 1,6 $\mathrm{g} / \mathrm{kg} \mathrm{BB}$ dengan perhitungan sebagai berikut : $250 \mathrm{mg} \mathrm{N} / \mathrm{kg}$ BB atau $201 \mathrm{mg} /$ $\mathrm{kg} \mathrm{BB}{ }^{0,75}$ dikalikan dengan faktor protein $=6,25$.

0,61 : efisiensi penggunaan protein untuk unggas yang sedang bertumbuh sebesar 61 persen

b. Untuk pertumbuhan jaringan $=(\mathrm{PBB} \times 0,18) / 0,61$

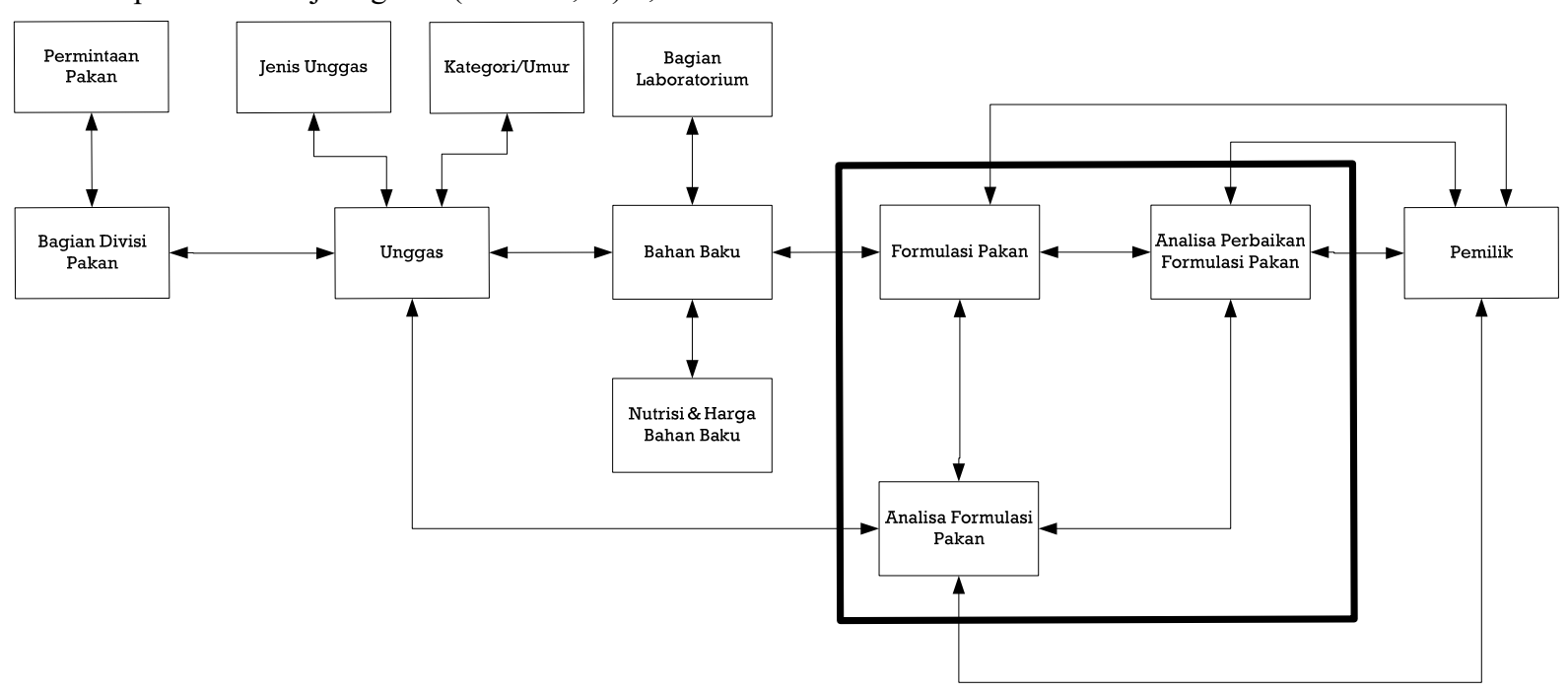

Gambar 1. Boundary Penelitian

\section{HASIL DAN PEMBAHASAN}

\section{A. Requirement Specification Document}

\section{Data Requirtment}

$\underline{\text { Staff }}$

Bagian divisi pakan bertugas mendata permintaan pembuatan pakan, mendata bahan baku yang akan digunakan, melakukan perhitungan formulasi, dan analisa formulasi. Data staff divisi pakan meliputi NIP, nama staff, alamat, kota, telepon, dan jabatan.

$\underline{\text { Bahan Baku }}$
PBB : pertambahan bobot badan

0,18 : bagian kandungan protein dalam karkas

c. Untuk pertumbuhan bulu $=(\mathrm{PBB} \times 0,07 \times 0,82) / 0,61$

0,07 : persentase berat bulu pada umur di atas 4 minggu sebesar 7\%, pada umur di bawah 4 minggu dikalikan dengan 0,04 atau 4\%

0,82 : kandungan protein bulu

Jika ada penyimpangan terhadap nilai nutrisi relatif, maka akan dibuat analisa perbaikan formulasi pakan dahulu dengan menggunakan sistem persamaan aljabar/Simultaneus equation method/persamaan $\mathrm{x}-\mathrm{y}$ jika terjadi perbedaan yang signifikan.

5. Setelah perhitungan formulasi didapat komposisi pakan $100 \%$ dan didapat angka nutrisi sesuai dengan kebutuhan, maka dibuat laporan hasil formulasi pakan yang berisi data formulasi beserta penggunaan komposisi bahan baku yang telah digunakan beserta laporan analisa formulasi pakan, tetapi jika ada penyimpangan terhadap nilai nutrisi relatif, maka dibuatkan juga laporan analisa perbaikan formulasi. Hasil dari perhitungan dan analisa yang sudah dibuat tersebut akan diserahkan kepada manajer produksi divisi pakan ternak unggas dan pemilik perusahaan sebagai laporan formulasi. 
yang akan digunakan sebagai informasi pakan dibuat untuk hewan apa. Kemudian akan melakukan perhitungan dengan memberikan nomor formulasi, kriteria formulasi lalu menambahkan komposisi bahan baku secara bertahap hingga akhirnya mencapai $100 \%$.

Analisa Formulasi Pakan

Analisa perhitungan formulasi ditentukan berdasarkan kebutuhan unggas. Cara penginputan dimulai dengan pemberian nomor analisa, pemilihan dasar kebutuhan, persamaan indeks dan bobot relatif unggas, dan hasil perhitungan formulasi yang akan di analisa.

Analisa Perbaikan Formulasi Pakan

Analisa perbaikan formulasi pakan dilakukan jika ada penyimpangan terhadap nilai nutrisi relatif. Hal ini dilakukan dengan memberikan nomor analisa perbaikan, mengambil data pada formulasi pakan dan hasil analisa

TABEL I

MAJOR USER VIEWS PADA SISTEM PEMBUATAN PAKAN

\begin{tabular}{|c|c|c|c|c|}
\hline Data & $\begin{array}{c}\text { Tipe } \\
\text { Akses }\end{array}$ & Pemilik & $\begin{array}{c}\text { Bagian } \\
\text { Labolatorium }\end{array}$ & $\begin{array}{c}\text { Bagian } \\
\text { Divisi } \\
\text { Pakan }\end{array}$ \\
\hline \multirow{3}{*}{$\begin{array}{l}\text { Permintaan } \\
\text { Pakan }\end{array}$} & Maintain & & & $\mathbf{x}$ \\
\hline & Query & & & $\mathbf{x}$ \\
\hline & Report & $\mathbf{x}$ & & $\mathbf{x}$ \\
\hline \multirow{3}{*}{$\begin{array}{c}\text { Bahan } \\
\text { Baku }\end{array}$} & Maintain & & & $\mathbf{x}$ \\
\hline & Query & $\mathbf{x}$ & & $\mathbf{x}$ \\
\hline & Report & $\mathbf{x}$ & & $\mathbf{x}$ \\
\hline \multirow{3}{*}{$\begin{array}{l}\text { Formulasi } \\
\text { Pakan }\end{array}$} & Maintain & & & $\mathbf{x}$ \\
\hline & Query & & & $\mathbf{x}$ \\
\hline & Report & $\mathbf{x}$ & $\mathbf{x}$ & $\mathbf{x}$ \\
\hline \multirow{3}{*}{$\begin{array}{l}\text { Analisa } \\
\text { Formulasi } \\
\text { Pakan }\end{array}$} & Maintain & & & $\mathbf{x}$ \\
\hline & Query & & & $\mathbf{x}$ \\
\hline & Report & $\mathbf{x}$ & $\mathbf{x}$ & $\mathbf{x}$ \\
\hline \multirow{3}{*}{$\begin{array}{c}\text { Analisa } \\
\text { Perbaikan } \\
\text { Formulasi } \\
\text { Pakan }\end{array}$} & Maintain & & & $\mathbf{x}$ \\
\hline & Query & & & $\mathbf{x}$ \\
\hline & Report & $\mathbf{x}$ & $\mathbf{x}$ & $\mathbf{x}$ \\
\hline
\end{tabular}

TABEL 2

USER VIEW MERGING

\begin{tabular}{|c|c|c|c|}
\hline See Views & Maintain & Query & Report \\
\hline Pemilik & & $\mathbf{x}$ & $\mathbf{x}$ \\
\hline \begin{tabular}{c|c|c|}
\hline Bagian \\
Labolatorium
\end{tabular} & & & $\mathbf{x}$ \\
\hline $\begin{array}{c}\text { Bagian Divisi } \\
\text { Pakan }\end{array}$ & $\mathbf{x}$ & $\mathbf{x}$ & $\mathbf{x}$ \\
\hline
\end{tabular}

\section{Transaction Requirements}

Data Masukan

a. Memasukkan data staff Divisi Pakan

b. Memasukkan data bahan baku

c. Memasukkan data formulasi pakan berdasarkan perhitungan komposisi bahan baku d. Memasukkan data analisa formulasi pakan berdasarkan hasil formulasi yang dibuat dengan dasar analisa

e. Memasukkan data analisa perbaikan formulasi pakan berdasarkan hasil formulasi dan analisa formulasi pakan

Pengubahan/Penghapusan Data

a. Ubah/hapus data staff Divisi Pakan

b. Ubah/hapus data bahan baku

Data Queries

a. Mendata bahan baku sebagai bahan utama pembuatan formulasi pakan

b. Mendata perhitungan formulasi pakan yang telah dibuat

c. Mendata analisa formulasi pakan yang dibuat dari hasil perhitungan formulasi pakan

d. Mendata analisa perbaikan formulasi pakan yang dibuat apabila terjadi penyimpangan pada analisa formulasi pakan

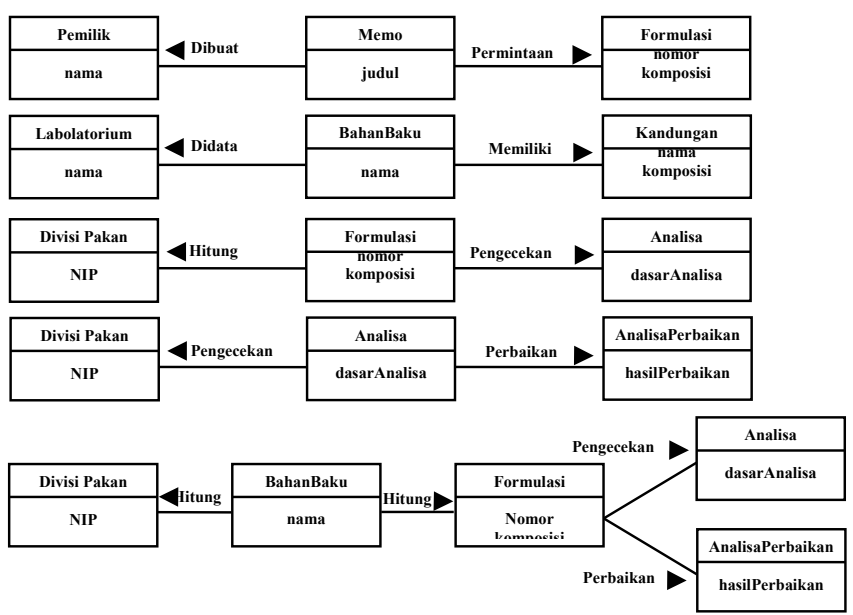

Gambar 2. Merging Local Data Model

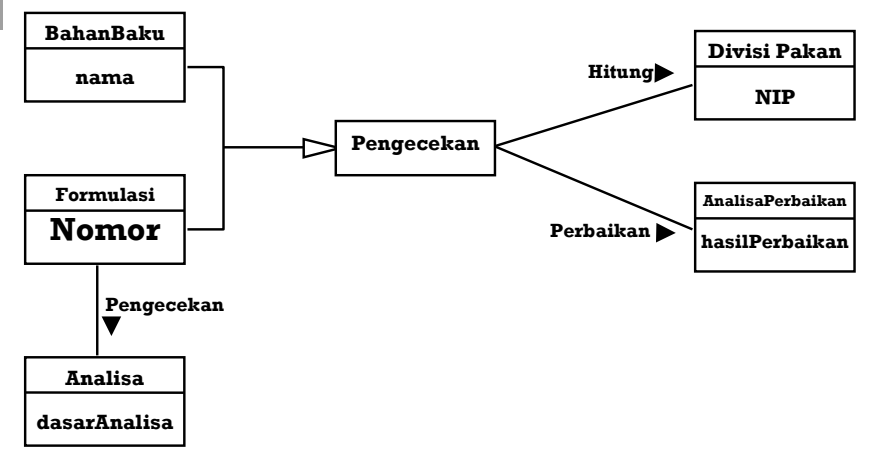

Gambar 3. Integrated View 
B. Conceptual Database Design

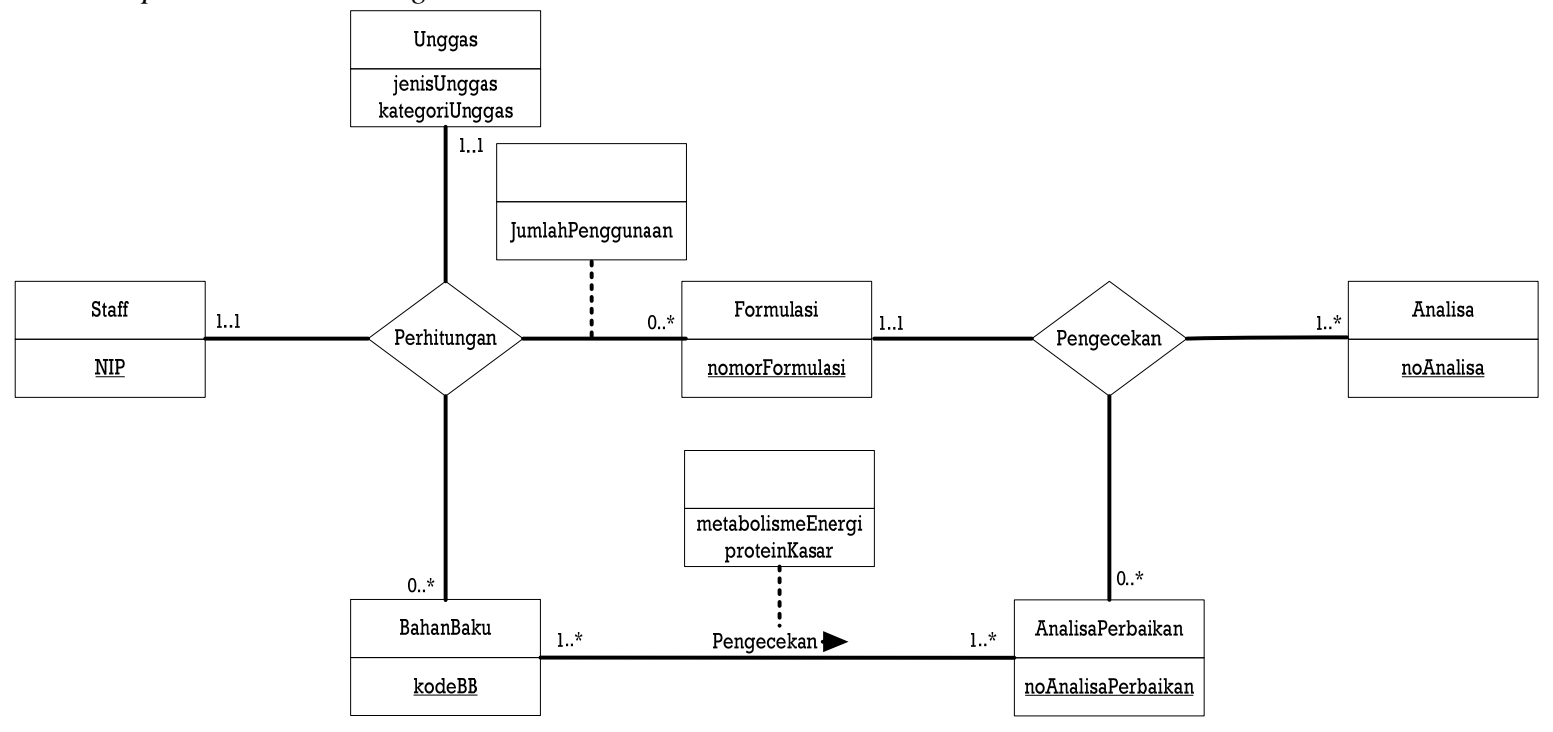

Gambar 4. Pembuatan ER diagram

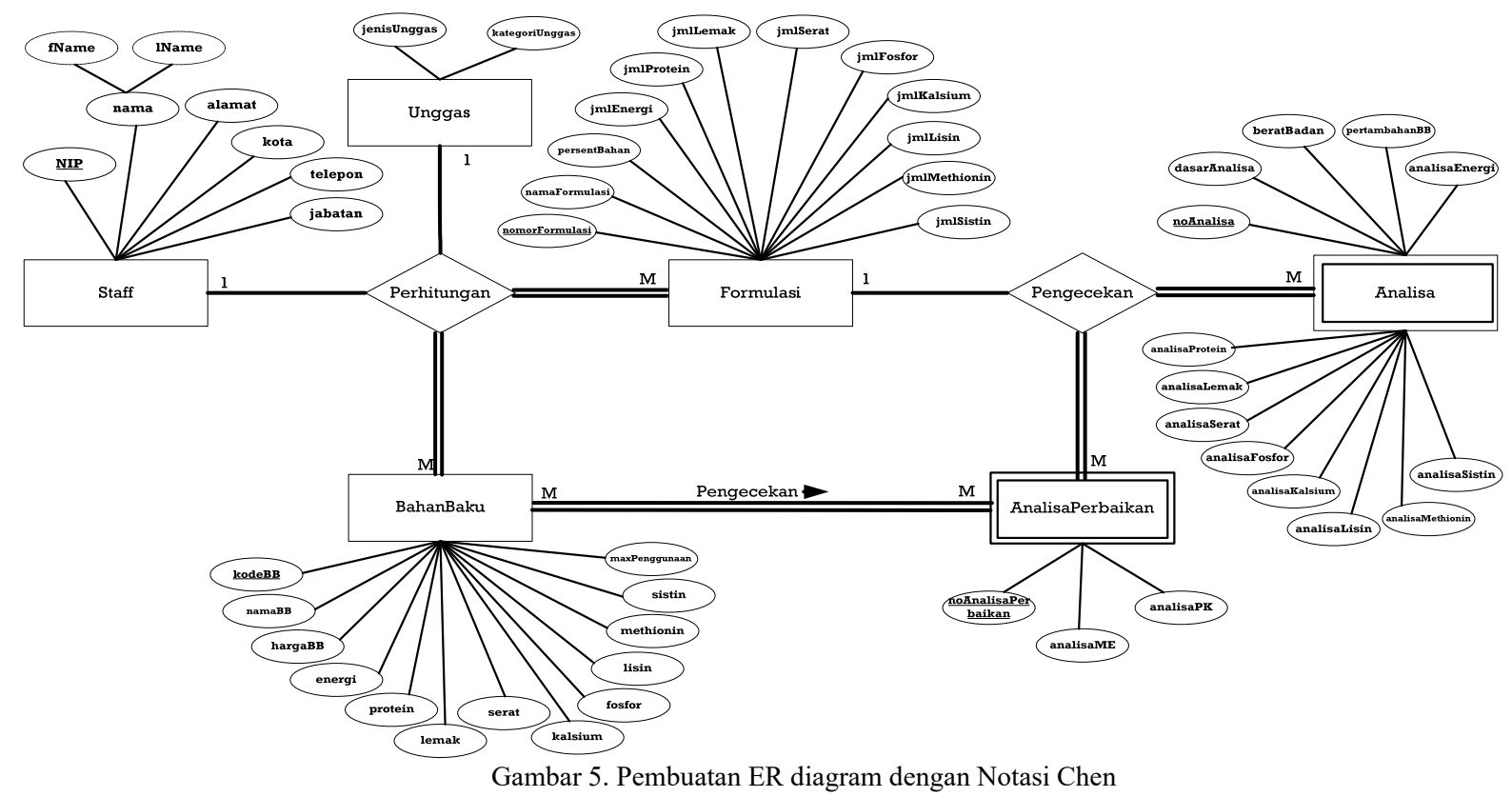

\section{Analisa Transaction}

1. Staff view

a) Insert/ enter bahan baku yang ada, perhitungan formulasi baru, analisa dari perhitungan formulasi baru, analisa perbaikan perbaikan jika ada penyimpangan.

b) Update/ delete bahan baku.

c) Megidentifikasi perhitungan formulasi, analisa dan analisa perbaikan saat terjadi penyimpangan.
2. Bahan Baku view

d) Mencatat kandungan energi, protein dan yang lainnya, beserta maksimal penggunaan pada setiap bahan baku.

e) Mencatat dan menghitung data komposisi pakan yang telah dibuat berdasarkan penggunaan bahan baku dan atas nama staff pembuatnya. 
Tabel 3

Transaction Pathway Diagram

\begin{tabular}{|l|l|l|l|l|l|l|l|l|l|}
\hline $\begin{array}{l}\text { Transaction } \\
\text { Relation }\end{array}$ & & \multicolumn{3}{|c|}{ (A) } & & (B) & (E) \\
\hline
\end{tabular}

\section{Keterangan Tabel:}

I=Insert; R=Read; U=Update; $\mathrm{D}=$ Delete

D. Implementasi Database

1. Pemilihan DBMS

Database yang dipilih untuk mengimplementasikan rancangan database yang telah dibuat dengan menggunakan Oracle Database $10 \mathrm{~g}$ atau Oracle Database $11 \mathrm{~g}$.

a. Tampilan pembuatan hak akses user

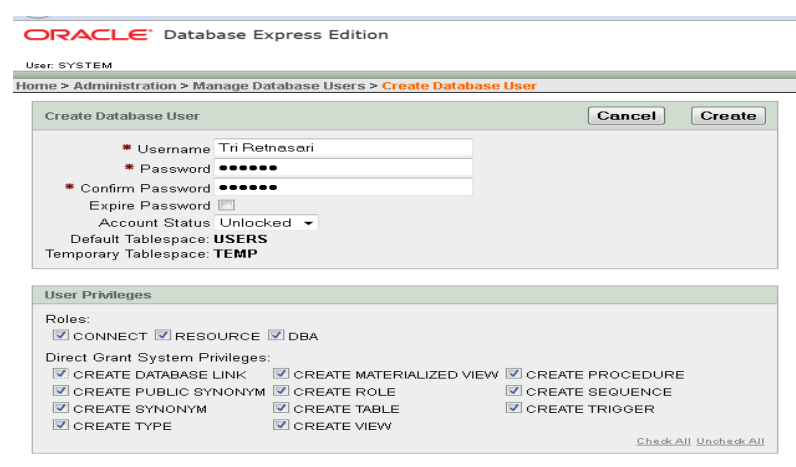

Lanquage: en-us

Gambar 6. Pembuatan Hak Akses User

b. Tampilan Homebase

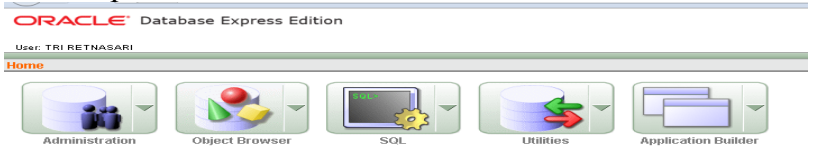

Langugas: an:us

Gambar 7. Homebase
2. Pembuatan DDL dan eksekusi/Run DDL

$$
\text { a. Tabel Staff }
$$
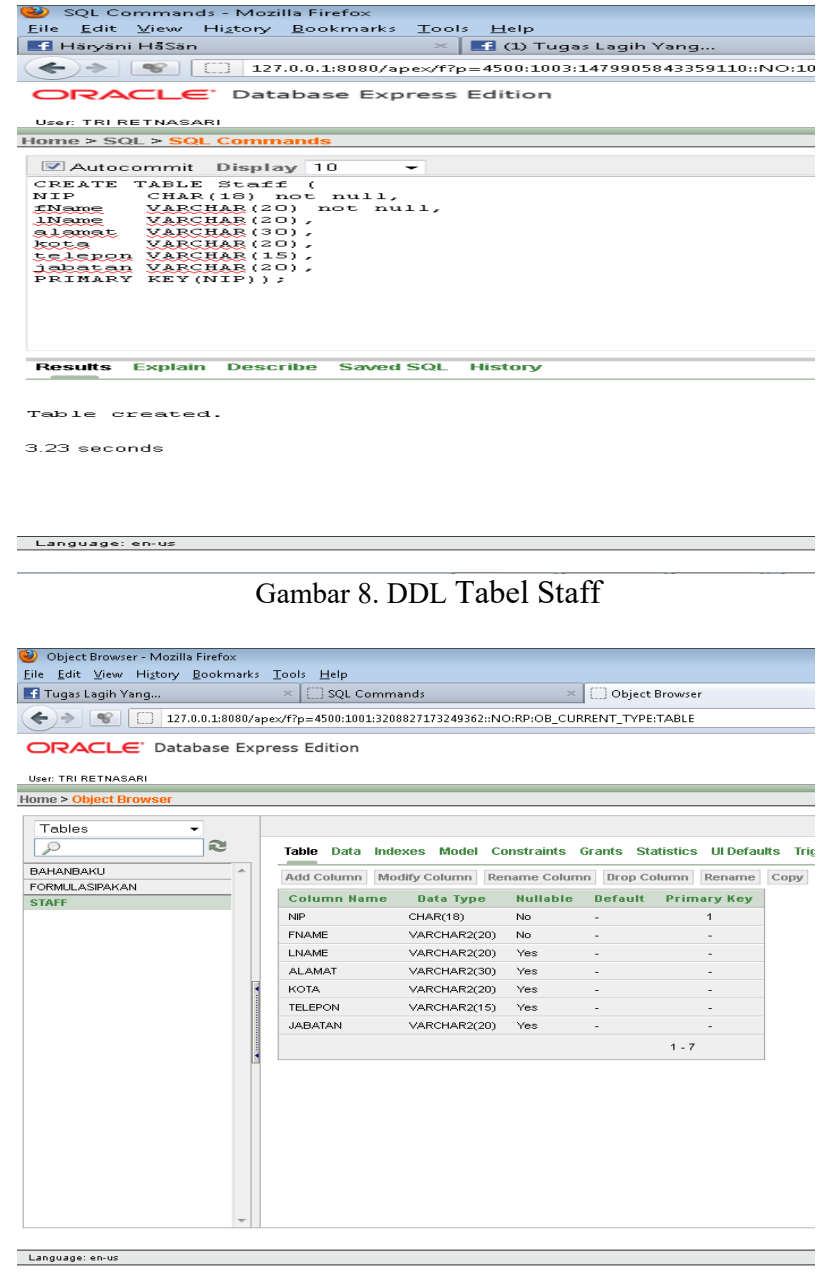

Gambar 9. Run DDL Tabel Staff 


\section{b. Tabel Bahan Baku}

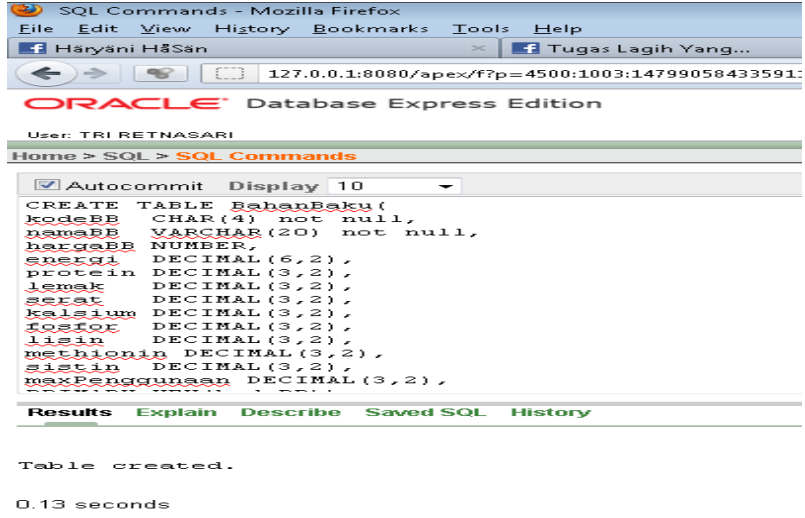

ㅁ. 13 secands

Lanauage: en-us

\section{Gambar 10. DDL Tabel Bahan Baku}

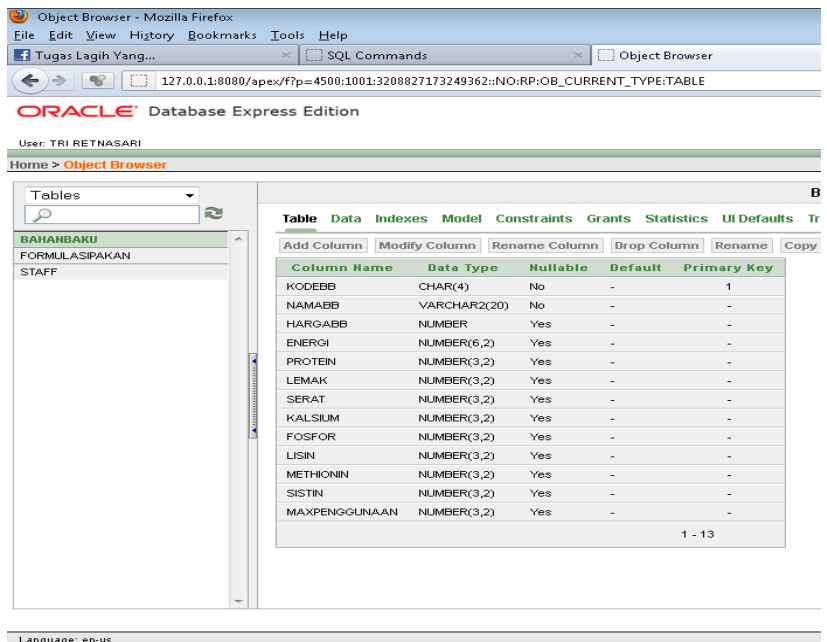

Longusges: en us

Gambar 11. Run DDL Tabel Bahan Baku

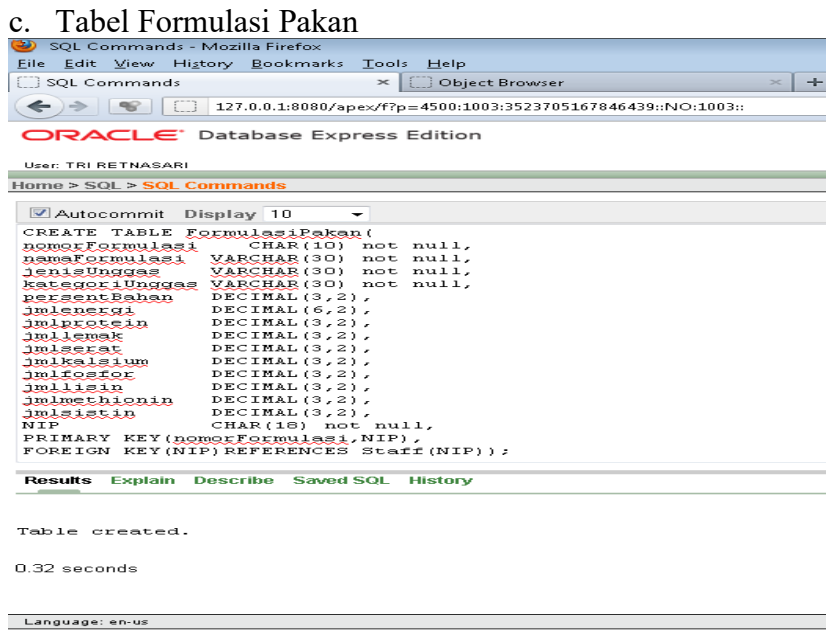

Gambar 12. DDL Tabel Formulasi Pakan

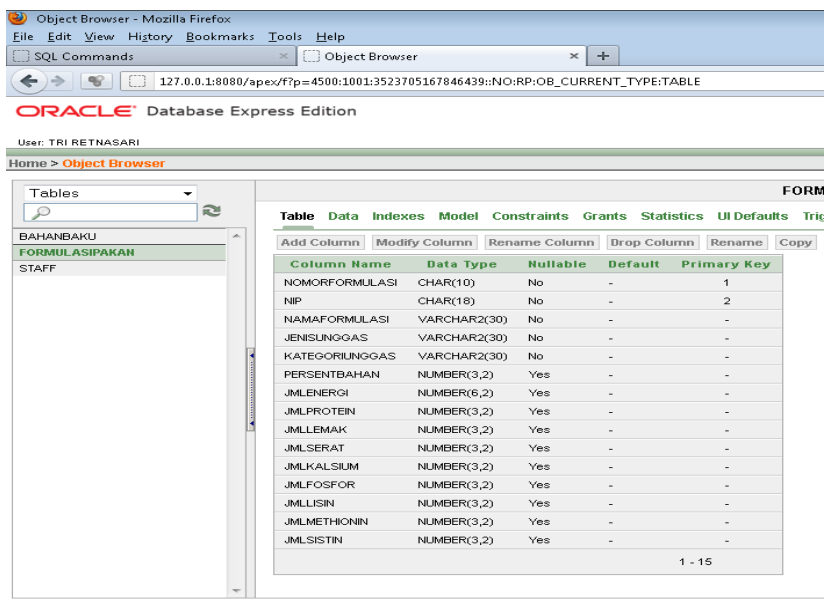

Lanouage: en-us

Gambar 13. Run DDL Tabel Formulasi Pakan

d. Tabel Perhitungan

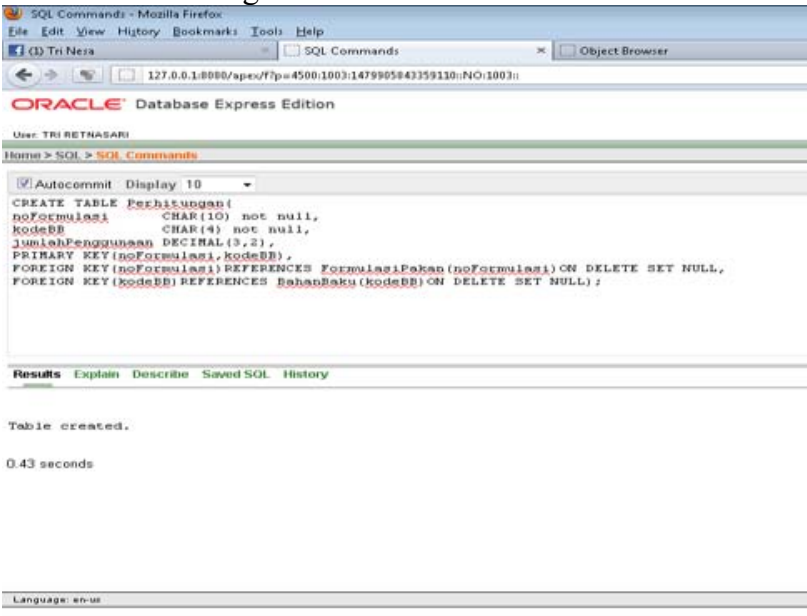

Gambar 14. DDL Tabel Perhitungan

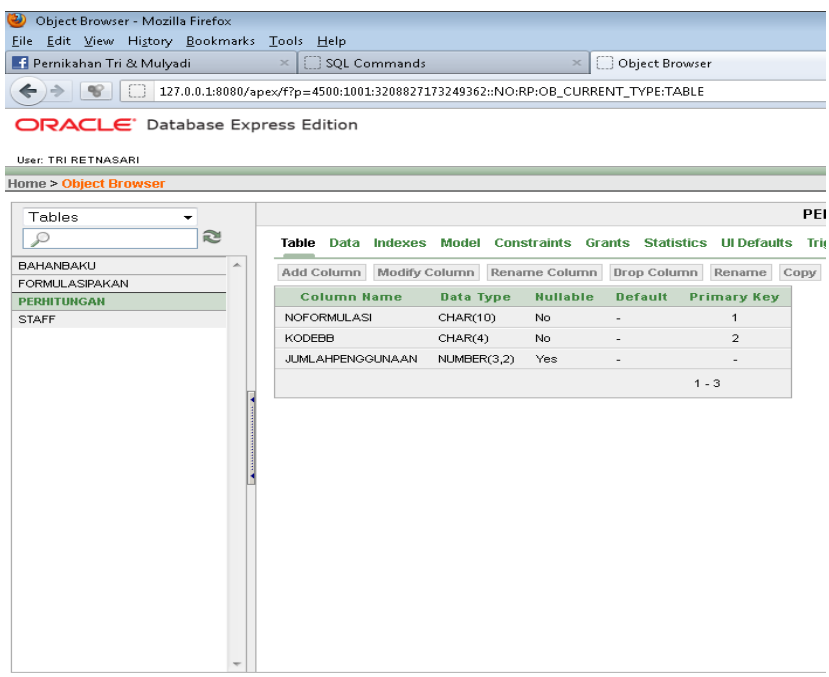

Language: en-us

Gambar 15. Run DDL Tabel Perhitungan 


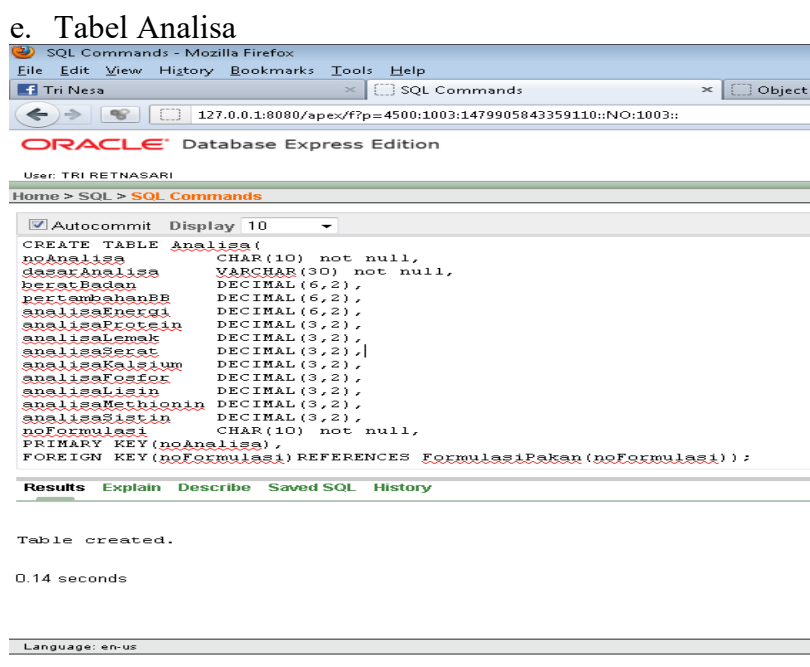

Gambar 16. DDL Tabel Analisa

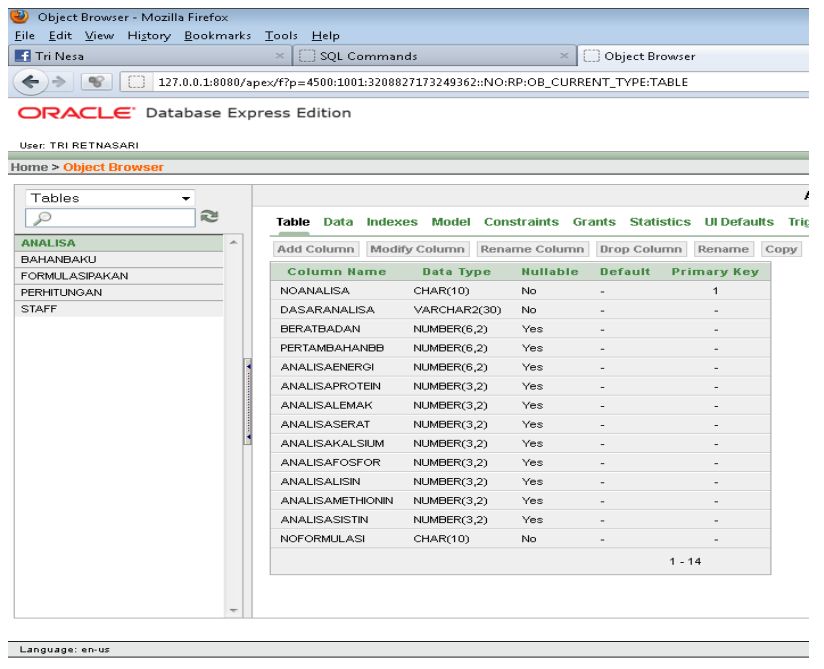

Gambar 17. Run DDL Tabel Analisa

f. Tabel Analisa Perbaikan
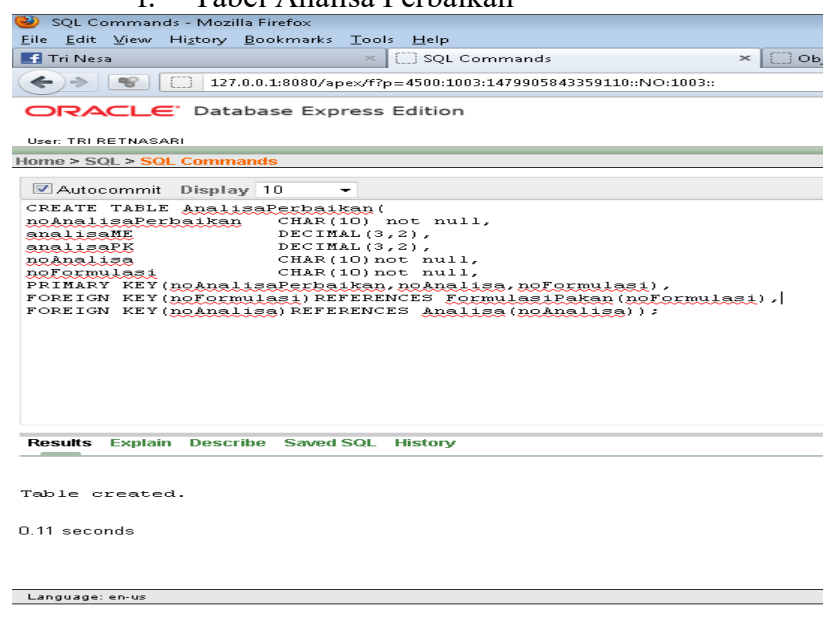

Gambar 18. DDL Tabel Analisa Perbaikan

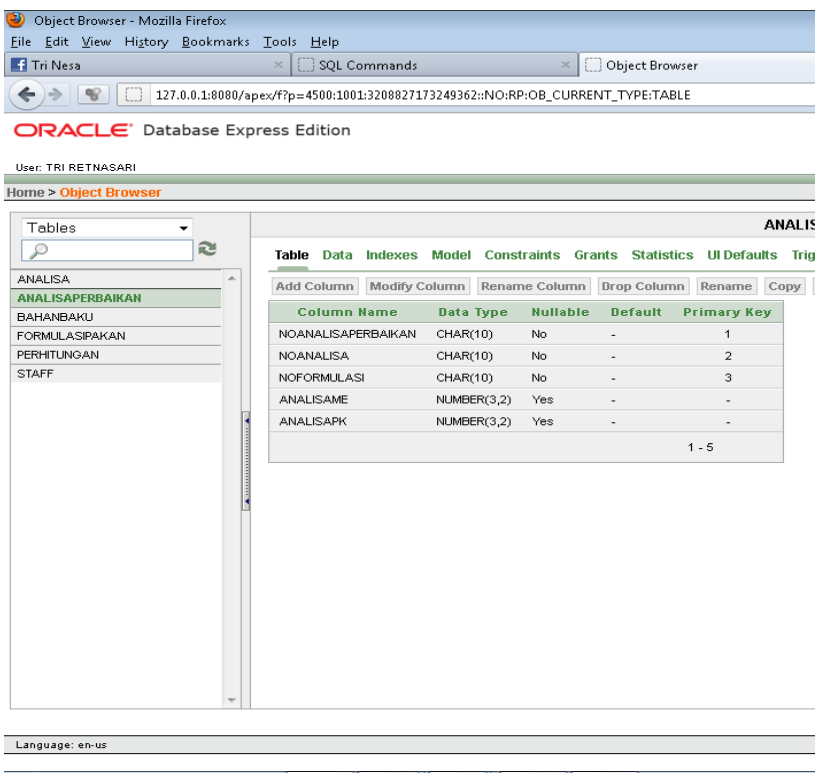

Gambar 19. Run DDL Tabel Analisa Perbaikan

\section{KESIMPULAN}

Dari hasil penelitian dan pembahasan maka dapat disimpulkan beberapa hal berikut:

1. Proses penggunaan sistem lama membutuhkan waktu yang cukup lama dalam melakukan penghitungan formulasi pakan karena banyaknya data serta proses pencatatan dilakukan secara berulang-ulang.

2. Analisa Sistem yang dirancang mempunyai 3 proses yaitu master, transaksi dan laporan. Dengan spesifikasi sebagai berikut :

a. Sistem yang dirancang memiliki master data bahan baku.

b. Selain itu, Memiliki 3 buah transaksi yaitu perhitungan formulasi pakan, analisa formulasi pakan dan analisa perbaikan formulasi pakan.

c. Dan juga menyediakan 3 laporan yaitu laporan formulasi pakan, laporan analisa formulasi pakan dan laporan analisa perbaikan formulasi pakan.

3. Pada perancangan sistem informasi formulasi pakan ini menggunakan konsep DBMS yang terdiri dari sebuah database dan 7 buah table yang terintegrasi dan saling berelasi.

\section{REFERENSI}

[1] Hadi, H., dan Hastuti, D., 2011, Kamus Terbaru Ekonomi dan Bisnis, Surabaya: Reality Publisher.

[2] Latief, Mukhlisulfatih, 2010, Pendekatan Database untuk Manajemen Data dalam Meningkatkan Kemampuan Mahasiswa Mengaplikasikan Konsep Basisdata, Seminar Internasional APTEKINDO, Gorontalo. ISSN: 1907-2066.

[3] Mansur, dan Kasmawi, 2017, Pengembangan Sistem Database Terpadu Berbasis Web Untuk Penyediaan Layanan Informasi Website Desa, Jurnal TEKNOSI Vol 03, No. 1.

[4] Nugroho, A., 2010, Rekayasa Perangakt Lunak Berorientasi Objek dengan Metode USDP, Yogyakarta: Andi. 
JIEET: Volume 02 Nomor 02, 2018

[5] Nurnawati, E.K., Ermawati, dan Ardyrusmaryya, D., 2016, Pemanfaatan basis data terintegrasi pada sistem informasi perangkat bergerak,Prosiding Sem inar Nasional Aplikasi Sain \& Teknologi (SNAST), Yogyakarta. ISSN: 1979-911X.

[6] Rosa dan Shalahuddin, M., 2013, Rekayasa Perangkat Lunak Terstruktur dan Berorientasi Objek, Bandung: Informatika Bandung.
[7] Sukamto, Sulistyo, W., dan Suyanto, B., 2012, Sistem terpadu rekam medic rumah sakit dengan smart card, Jurnal Informatika Vol 6, No. 1.

[8] Yuhefijar, 2008, Konsep Dasar Sistem Informasi Akuntans, Jakarta: Salemba Empat. 